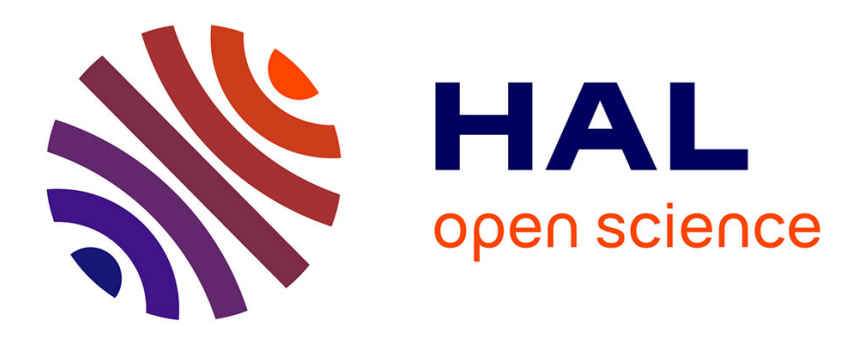

\title{
In Defense of the Numeral-based Model of Austronesian Phylogeny, and of Tsouic \\ Laurent Sagart
}

\section{To cite this version:}

Laurent Sagart. In Defense of the Numeral-based Model of Austronesian Phylogeny, and of Tsouic. Language and Linguistics, 2014, 15 (6), pp.859-882. 10.1177/1606822X14544623 . halshs-02546561

\section{HAL Id: halshs-02546561 \\ https://shs.hal.science/halshs-02546561}

Submitted on 30 Apr 2020

HAL is a multi-disciplinary open access archive for the deposit and dissemination of scientific research documents, whether they are published or not. The documents may come from teaching and research institutions in France or abroad, or from public or private research centers.
L'archive ouverte pluridisciplinaire HAL, est destinée au dépôt et à la diffusion de documents scientifiques de niveau recherche, publiés ou non, émanant des établissements d'enseignement et de recherche français ou étrangers, des laboratoires publics ou privés. 


\title{
In defense of the numeral-based model of Austronesian phylogeny, and of Tsouic ${ }^{*}$
}

\author{
Laurent Sagart \\ Centre de Recherches Linguistiques sur l'Asie Orientale, \\ Centre National de la Recherche Scientifique
}

This paper responds to all of Malcolm Ross's criticisms, published in L\&L 13.6 (2012), of Sagart's numeral-based model of Austronesian phylogeny (Sagart 2004). It shows that a part of these criticisms is addressed to an invented version of Sagart's model, while another appeals to questionable principles. It points out various errors of fact and interpretation. It also criticizes Ross's own account of the evolution of early Austronesian numerals, showing that it has little explanatory power, fails to account for phonological irregularities, and cannot explain the observed nesting pattern among numeral isoglosses. Finally, this paper shows that Tsouic, a Formosan subgroup which contradicts Ross's phylogeny, is valid.

\section{1 background}

Sagart (2004) presented a new model of the early phylogeny of the Austronesian family, particularly its Formosan phase. The model placed the PAn homeland in northwest Taiwan, treated ProtoMalayo-Polynesian as a member of a low-level Formosan subgroup and Tai-Kadai as a sister group to Malayo-Polynesian. The argument relied on a set of innovations among numerals, revealed mainly by two independent lines of evidence: first, the observation of a hierarchy of implications among the familiar cardinals from 5 to 10 , such that:

$$
\begin{aligned}
& \text { *puluq ' } 10 \text { ' }<<\text { Siwa ' } 9 \text { ' }<<* \text { walu ' } 8 \text { ' }<<* \text { enem ' } 6 \text { ' }<<* \text { lima ' } 5 \text { ' }<<\text { pitu '7' } \\
& \text { (where 'A }<<\text { B' means 'a reflex of A implies the presence of a reflex of B') }
\end{aligned}
$$

Similarly among biological species the presence of hair implies amniotic eggs, which imply four limbs, which imply a bony skeleton, which implies vertebrae. Nesting of characters in a set of species or languages results from successive innovations in a line of descent: the degree of nesting is an index of a character's position in the relative chronology of changes. If, instead of being innovations, *puluq etc. were PAn retentions, the nesting pattern would be inexplicable. Second,

* The authors wishes to thank Anton Antonov, Guillaume Jacques and Thomas Pellard for useful discussion, and two anonymous reviewers for suggesting improvements to this paper. This work is part of the program Investissements d'Avenir, overseen by the French National Research Agency, ANR-10-LABX-0083, (Labex EFL). 
Sagart (2004) confirmed the innovative nature of three of the relevant numerals: *pitu, *walu and *Siwa, by showing that they can be derived from longer PAn additive constructions, synchronically attested in the northwest Formosan language Pazeh. The proposed derivation assumed six ordered sound changes which however did not apply outside of compound numerals.

The tree (not shown here) published in Sagart (2004) used subgroup names based on the numeral innovation which defines them, for instance 'Pituish', 'Enemish' etc. That tree suffered from two errors. The first concerned Papora and Hoanya, whose position above Enemish did not match the fact that they reflect all of *enem, *walu and *Siwa, and must therefore be Walu-Siwaish languages. The second concerned the Muish group. 'Muish' was defined not by a numeral innovation but by the politeness shift of the personal pronoun *-mu from 2 pl genitive to $2 \mathrm{sg}$ genitive, shown by Blust (1977) to be a Proto-Malayo-Polynesian trait. Based on an unpublished text recorded by Asai, Li (1995:667) claimed the shift had also taken place in Trobiawan, a northeast Formosan language. ${ }^{1}$ This seemed to justify a Muish subgroup of Walu-Siwaish containing Trobiawan and Malayo-Polynesian. However, Li later (1999:485) glossed the same text in a way that showed the relevant pronoun was really a plural. This removed the principal argument for the Muish group, and I consequently abandoned it (Sagart 2006, 2008). I had earlier dismissed another possible lower-order subgroup, defined by the possession of *puluq for ' 10 '. The demise of Muish removed objections to Puluqish. Puluqish includes Proto-Malayo-Polynesian and three WaluSiwaish languages of southeast Taiwan: Amis, Puyuma and Paiwan. The Tai-Kadai languages reflect *plut (Ostapirat 2000) instead of expected *pluk (expect Tai-Kadai *-k for AN *-q, Ostapirat 2005): this is explained in Sagart (2010b). The new tree (Figure 1) describes my current understanding of early AN phylogeny: it reflects the abandonment of Muish and the adoption of Puluqish. It introduces a Limaish node (for *lima ' 5 '), intermediate between Pituish and Enemish, and includes a Tsouic subgroup nested within Rukai-Tsouic. The Tai-Kadai and Malayo-Polynesian clades are subsumed within a new 'Southern Austronesian' branch which is part of Puluqish.

1 "(...)Trobiawan (...) uses the form imu 'your (sg)' as in tama-imu 'your father' (...) rather than (i)su as in most Formosan languages.": 


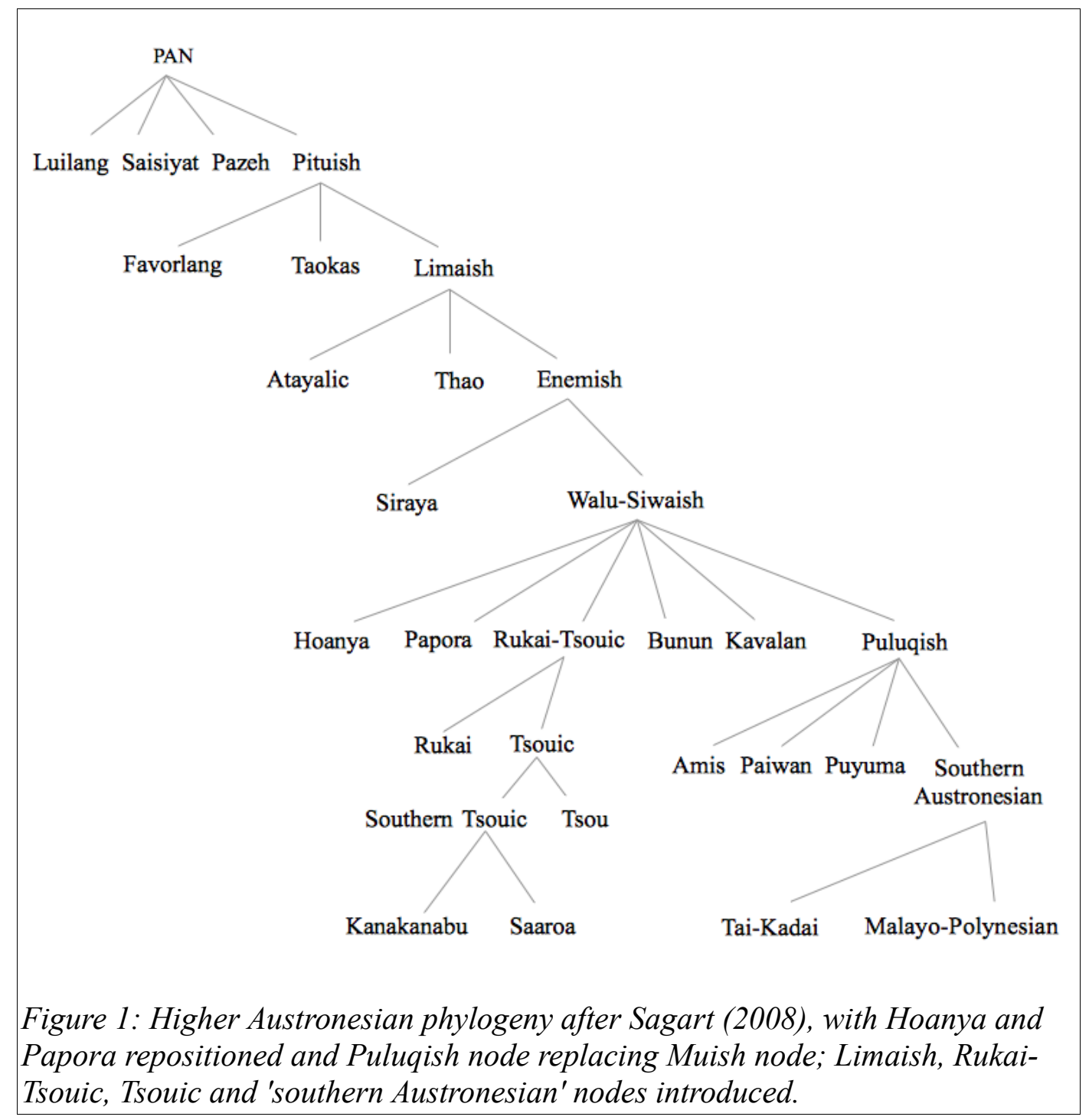

In order to allow readers to follow step after step the development of the hypothesized PAN numerals as they were successively affected by the six sound changes mentioned earlier, Sagart (2004) presented his evolutionary model in tabular form, as Table 2 of that paper. That table is reproduced, unchanged from Sagart (2004), as Figure 2 below. It was presented as a means to establish "that phonetic evolution from the long to the short forms is possible and that it requires only the application of a small number of natural sound changes" (p. 419). Sagart (2004:418) also pointed out that "there are several possible variants of this derivation". 


\begin{tabular}{|c|c|c|c|c|c|c|c|}
\hline & $\begin{array}{l}\text { o. } \\
\text { start } \\
= \\
\text { PAN }\end{array}$ & $\begin{array}{l}\text { I. } \\
\text { schwa } \\
>\mathrm{i} \\
\text { after -iC }\end{array}$ & $\begin{array}{l}2 . \\
\text { pa } \\
> \\
\text { wa }\end{array}$ & $\begin{array}{l}3 . \\
\text { delete } \\
\text { remaining } \\
\text { schwas }\end{array}$ & $\begin{array}{l}4 . \\
\text { prune } \\
\text { left of } \\
\text { pretonic } \\
\text { syllable }\end{array}$ & $\begin{array}{l}5 . \\
\text { prune } \\
\text { right of } \\
\text { stressed } \\
\text { vowel }\end{array}$ & $\begin{array}{l}6 . \\
\mathrm{tl} \\
> \\
\mathrm{t}\end{array}$ \\
\hline $7(5+2)$ & RaCep-i-tuSa & RaCepituSa & RaCepituSa & RaC_pituSa & _pituSa & pitu_ & pitu \\
\hline $8(5+3)$ & RaCep-a-telu & RaCepatelu & RaCewanatelu & RaC_wat_lu & _watlu & watlu & walu \\
\hline $9(5+4)$ & RaCep-i-Sepat & RaCepiSipat & RaCepiSiwat & RaC_piSiwat & _Siwat & Siwa & Siwa \\
\hline
\end{tabular}

Figure 2: Changes deriving *pitu, *walu and *Siwa from PAn additives. Reproduced from Sagart (2004).

The forms at stage 0 in Figure 2 are PAN reconstructions for ' 7 ', ' 8 ', ' 9 '. To the exception of the voiceless initial in *tuSa they are directly reflected in Pazeh xasepidusa, xasepatelu, xasepisupat. Vowels in bold type are assumed to have been stressed. See Sagart (2004) for an explanation of voiceless *t and penultimate stress in ' 7 '. Stages 1 through 6 show the evolution of the PAN forms as they are successively affected by six sound changes, described in the top row. The output of one change is the input of the next one. At each stage, underlines mark segments affected by a change. Deletions are represented by underlined blanks. The forms at stage 6 are the output of the sequence of changes: they are identical with the forms usually reconstructed for ' 7 ', ' 8 ' and ' 9 '.

Few objections were raised against the fact of the hierarchy of implications. The etymologies for *pitu, *walu and *Siwa on the other hand were rejected by Winter (2010) on the ground that the sound changes involved are ad hoc and irregular. Sagart (2013a) answers this concern and all the other objections of Winter's. The present paper is intended as a response to Ross (2012), where that author updates the phylogenetic proposal in Ross (2009), critically discusses alternative ones, including the numeral-based model in Sagart (2004), and develops an argument against Tsouic, a proposed Formosan subgroup which clashes with his claims. Since Ross's paper does not discuss the position of Tai-Kadai, this point will not be addressed here. Section 2 of this paper compares the methodologies in Sagart (2004) and Ross (2009, 2012). Section 3 answers Ross's objections. Section 4 discusses Ross's account of Formosan numerals, which is much influenced by $\mathrm{Li}$ (2006). Section 5 argues that Tsouic is a valid subgroup.

\section{Comparing the methodologies}

\section{1 single vs. multiple characters}

Both studies accept that language classification should be based on innovations. Sagart (2004) built his phylogeny from six independent innovative numerals forming a natural set, thus avoiding character-handpicking. This (multiple characters, no handpicking) is in agreement with modern 
phylogenetic practice. Ross sees no harm in basing a phylogeny upon a single innovation, so long as it is a complex morphosyntactic character manifested in several markers simultaneously. However this then induces another difficulty: marking individual languages as 'yes' or 'no' for such complex traits can be controversial — see the second opinions on Puyuma, a crucial part of Ross's argumentation, in Sagart (2010a, 2013b). This poses with acuity the question of what body of confirmed innovations Ross's single-character, single-node phylogeny is compatible with.

\section{2 subgrouping value of sound changes}

Both studies agree in finding sound change (regular sound change in Sagart's case) to be of little value due to the risks from parallel innovations and from spreading of sound change across language boundaries. Sagart criticized Blust's phonologically-based subgrouping (Blust 1999a), arguing that spreading is an inherent property of regular sound change (2004:412). In contrast, Ross (2009:305-306) made a virtue of the partial compatibility of his phylogeny with Blust's, even describing a scheme combining the two models. He now (2012:1262) sees that the phonological innovations behind each of the subgroups in Blust (1999a) are not 'coterminous', i.e. they do not characterize the same sets of languages. This leads him to silently abandon the theme of compatibility with Blust's scheme, coming close to the position in Sagart (2004:412) that the contribution of regular sound change to Formosan classification is negligible.

The same is not true of irregular or sporadic sound change. Perhaps because they are less easy to detect and thus less able to become invested with social affect, or because they target individual words which either exist in a different phonetic shape, or do not exist at all, on the other side of of a language boundary, irregular or sporadic changes appear to be good markers of linguistic ancestry. See Marck (2000) for an application to Polynesian languages; cf. also the occasional use of irregular changes like metatheses in Blust's classification (1999a). Some Tsouic examples will be given below.

\section{3 subgrouping value of morphological innovations}

A third area of agreement concerns the high value of morphological changes. Ross (2012:1259) cites Ringe et al. (2002) to the effect that inflectional systems are tightly integrated idiosyncratic constructs, so that "conditions which would give rise to similar changes are unlikely to recur in different languages". But this is a double-edged sword. Precisely because they are tightly integrated constructs, innovations in them can induce far-reaching reorganizations of the entire system which, in turn, lead to the loss of entire subsystems, and to earlier innovations being erased in numbers. Such is the case in Tsou, discussed in section 5.2 . 


\section{4 subgrouping value of lexical innovations}

The main point of disagreement bears on the subgrouping value of lexical innovations. Ross again citing Ringe et al. (2002) states that lexical innovations are the least secure kind of evidence that can be used in subgrouping, (again) because of the risks from independent innovation and from spreading. The first kind of risk, however, is just as serious with morphological innovations. As Sagart (2004) argued, the risk from spreading can be reduced by selecting characters from lists of basic vocabulary (admittedly not a well-defined notion). Ross sees a third problem with lexical innovations: 'it is sometimes difficult to know which word is original and which word is the replacement' (1262). This is true but trivial. More to the point, it is sometimes possible to know which word is original and which one is innovated. Historical linguists can take their cues from accumulated knowledge on the directionality of semantic changes; on the spatial distribution of etyma for a given notion; on the expected correlation between time since innovation and degree of opacity of a word; etc. For an illustration, see the discussion of the Tsouic innovations for ' 1 ' and 'hand' in section 5 below.

Lexical innovations possess an important advantage over morphological ones. The lexicon is more amorphous and less tightly structured than morphosyntax. For that reason single lexical innovations are less likely to trigger cascades of other lexical changes. As such the lexicon offers a more even, and more detailed record of phylogenetic history than morphosyntax. This is why lexical innovations, especially from the basic vocabulary, are so broadly used in modern phylogenetic studies. In the very paper where they expressed distrust of lexical evidence, Ringe et al. (2002) constructed an Indo-European phylogeny from a predominantly (90\%) lexical data-set: 333 lexical characters out of 370 .

All in all, wherever possible, a robust phylogeny should be based on a panel of innovations in the basic vocabulary, in morphosyntax as well as some irregular or sporadic sound changes.

\section{Ross's criticisms of the numeral-based model}

Ross's criticisms of Sagart's numeral-based model (referred to as 'hypothesis A') on pp. 1285-1288 are addressed exclusively to Sagart (2004); he makes no mention of Sagart (2008). His critique of the Muish node duplicates the points already made in Sagart (2008), summarized in section 1 above. Below I respond to the other criticisms in Ross (2012), in the order that he presented them.

Ross's discussion opens at the bottom of p. 1285 on a consideration of the phonetic evolution of the numerals '7', '8', '9' proposed in Sagart (2004). Curiously, instead of addressing the changes set out in Table 2 of Sagart (2004), reproduced as Figure 2 above, he discusses a model of his own which unfortunately has little to do with the original. He begins by claiming that "each 
of the three derivations (...) assumes a different set of changes". Figure 2 shows that this is false. Ross elaborates: "First, *-p- is preserved as *p- in '7', but has become *w in '8' and '9'”. The change of $*_{p}$ to ${ }^{*} \mathrm{w}$ is actually formulated at stage 2 of Figure 2 as "pa- $>$ wa", that is, as conditioned by a following low vowel. Authors have long argued that low vowels facilitate lenition of stops (summary in Kingston 2008, who disagrees). An Austronesian example is the lenition of *b to $w$ when flanked by two *a's in Malay: *baba > bawa 'carry', *laban > lawan 'against', *tabaR > tawar 'tasteless' etc. (Adelaar 1992, Wolff 2010). Next: "Second, to account for loss of *-te- in '8', stress is assigned to the forms on the left and unstressed syllable deletion is assumed, yielding *walu from *patelú". I am puzzled. An intermediate * patelú stage cannot be found at any point in my derivation, and by Figure 2, no stress is assigned to any "forms on the left" and no "unstressed syllable deletion is assumed". Ross goes on: 'If the changes that affect ' 8 ' had also affected '9', they would yield †*wiwat from *piSepát". No. Ross's *wiwat is not a possible outcome of the changes in Figure 2 for these obvious reasons: (1) *p does not change to w before $\mathrm{i}$; (2) there is no change deleting $* S$; (3) the first vowel in *Sepat escapes deletion at stage 3 because (unlike the first vowel in *telu) it has been changed to a front vowel through an assimilatory change at stage 1; (4) change 5 prunes *RaCpiSiwat left of the pre-tonic syllable -Si-, that is, it prunes all of RaCpi-; (5) final - $t$ in the resulting form is deleted by change 6. Ross continues: "Associated with this is the fact that in the forms for ' 7 ' and ' 8 ' pruning from the left deleted RaCe... but in ' 9 ' RaCepi...'. No again: by Figure 2, left pruning occurs at stage 4, affecting the output of stage-3 forms: RaCpituSa '7', RaCwatlu '8', RaCpiSiwat '9'. The pruning rule says "prune left of pre-tonic syllable”. This means prune left of -pi- in '7', of -wat- in ' 8 ' and of -Si- in '9'. Finally, Ross: “* Siwa also entails finalconsonant deletion, whilst ' 7 ' reflects -CV deletion, neither of which is otherwise attested in Formosan languages". This refers to change 5 "prune right of stressed vowel”. At least three examples of final consonant deletion can be cited, all — significantly — from compound numerals. First, Pazeh \#137a (Li and Toyoshima 2006) has supat '4' but hasubisupa '9'. Second, PAN *iCit '10' (Pazeh isit, Luilang isit; Favorlang zchiett [tsxiet], Taokas ta-isid $<* \mathrm{~s}(\mathrm{a})$-iCit 'one-ten') unexpectedly loses -t in Hoanya mia-ta-isi and Papora metsi, both '10'. Hoanya and Papora otherwise preserve final -t: Hoanya (mia)pat, Papora (ne)pat, both '4'. Final -t is also lost in Sideya (Siraya) kytti '10' (<*k-iCi(t), as cited in Li and Toyoshima (2006:669, \#145, \#147, \#148). Third, in the Siraya Gospel of St. Matthew, studied in Adelaar (2011), '4' is cited as hpat, ahpat, pat, pahpat (=xpat, a-xpat, pat, pa-xpat in Adelaar's restored pronunciation), all with inherited final -t from *Sepat. But in the multiplicative compound kouyhpa ' 8 ' (=kuixpa), loss of -t has occurred. I am unable to document the existence of final $\mathrm{CV}$ deletion processes in Formosan languages, however. This may point to an inadequacy in the model set out in Figure 2. Meanwhile it is patent 
that Ross has not grasped the phonetic evolution proposed in Sagart (2004).

Sagart (2004:419) noted that the initial consonant in Amis falu ' 8 ' $<$ early Amis *balu is better explained as coming from a PAN stop such as the -p- in * RaCep-a-telu than from the w- in *walu. Ross (2012:1286 fn. 36) writes that "the data in Tsuchida (1981) show that the Proto Amis form was *waLu and that falu is a recent development". He seems not to have realized that the form valo? ' 8 ' given by Tsuchida in twelve Amis dialects (out of nineteen) reflects *balu, not *walu. ${ }^{2}$ The sound noted as $v$ by Tsuchida is noted as $f$ by other authors (for instance in Table 1 below). At the same time, seven Amis dialects show walo?, all reflecting *walu. Proto-Amis, then, must have had an alternation between *balu and *walu. Unfortunately the evidence at hand does not tell us how the two differed. Outside of Amis none of the best-described modern Formosan languages reflects *balu for ' 8 ', but a few varieties from Ogawa's notebooks (Li and Toyoshima 2006) do so: Bunun \#33 bau, Tsou \#38c, \#40b boyu, boyu, where b reflects *b. Tanan Rukai as recorded in the 1910's by a team of Japanese investigators (point \#56f in Li and Toyoshima 2006) even contrasts a $v$-form $(<* \mathrm{w})$ and a $b$-form $(<* \mathrm{~b})$ : valo ' 8 ' vs. ka-balu-an 'the eighth month'. Similarly $b$-forms of ' 9 ' (i.e. siba or the like) were recorded in Bunun, Tsou, Rukai, and Paiwan. Three Paiwan varieties (ibid., $\# 65 \mathrm{~g}, \# 65 \mathrm{~h}, \# 65 \mathrm{i})$ documented by the same team of Japanese investigators, contrast siba '9' $(<* \mathrm{~b})$ and $k \bar{a}-$ siwa-y-an or ka-siva-n 'the 9th month' $\left(<{ }^{*} \mathrm{w}\right)$ (Table 1). The ${ }^{*} \mathrm{~b} \sim{ }^{*} \mathrm{w}$ alternation in ' 8 ' and ' 9 ' is seen in five contiguous Walu-Siwaic languages: Bunun, Tsou, Rukai, Paiwan and Amis. We can be certain that this alternation does not originate in a recent Amis innovation.

\begin{tabular}{|l|l|l|}
\hline & reflecting *b (b-forms) & reflecting *w (w-forms) \\
\hline Amis & falu '8' (Fata'an, Farang dialects) & walu '8' (Sakizaya dialect) \\
\hline Tanan Rukai \#56f & ka-balu-an '8th month' & valo '8' \\
\hline Paiwan \#65g & siba '9' & kä-siwa-y-an '9th month' \\
\hline Paiwan \#65h & siba '9' & $k a-$ siva-n '9th month' \\
\hline Paiwan \#65i & siba '9' & $k a-$ siva-n '9th month' \\
\hline
\end{tabular}

Table 1: Alternations between ${ }^{*} b$ and $*^{*} w$ in ' 8 ' and '9'. Sources: Li (2004:1529) for Amis; Li and Toyoshima (2006) for Rukai and Paiwan.

If *walu and *Siwa were the PAn words for ' 8 ' and ' 9 ', the $b$-forms in Table 1 would have to be parallel and sporadic fortitions of ${ }^{*} \mathrm{w}$ without a clear motivation. In the present model, the $b$ -

2 For instance Fata' an ('VAT' in Tsuchida's document) has $v<*$ b in valo? ' 8 ' $<*$ balu, sa-vaLat 'southern wind' $<$ *sa-baRat, va? Loh 'new' < *baqeRuh, vaLaQ 'lung' $<*$ baRaq, vava? 'carry on back' $<$ *baba, vavoy 'pig' $<$ *babuy, viLviL 'lips' $<$ *biRbiR, vokes 'hair' $<$ *bukeS, voLal 'moon' $<$ *bulaN etc. against $w<*$ w as in ka-wanan 'right' < *ka-waNan, waLi? 'east' <*waRi, LawaL 'squirrel' < *lawaR, walis 'teeth' < waNiS, wili? 'leech' < *wiliH etc. 
forms and $w$-forms are intervocalically voiced and lenited outcomes, respectively, of PAn *p preceding a low vowel in compound numerals, a more natural and convincing proposition.

Ross next turns to "the evidential basis of Sagart's reconstructions". His objections bear on the reconstruction of the PAn words for ' 2 ' and ' 5 '. The PAn word for ' 2 ' is usually reconstructed with a voiced stop initial, e.g. Blust's *duSa. ${ }^{3}$ Sagart (2004) assumes PAn *duSa had a variant PAn *tuSa, with initial *d- changed to *t- on the analogy of PAn *telu '3' (similarly Russian devjat' '9' has initial $d$ - in place of expected $n$-, on the analogy of desjat' ' 10 '). PAn *tuSa may have served in serial counting, as suggested by Puyuma (below). Ross denies the existence of a variant *tuSa. In its support, Sagart (2004) had cited Thao tufa, Amis tosa and Puyuma (Rikavong) towa. Ross (2012:1286) reconstructs ' 2 ' as PAn *Dusa, with PAn *D, a controversial PAn phoneme, of which he says that Thao $t$ is 'arguably' the regular reflex: according to him only Amis tosa reflects a possible PAn *tuSa. He forgets the Puyuma serial-counting forms: Rikavong towa '2' (Suenari 1969:152) and Tamalakaw tuwa '2' (Tsuchida 1980:287). He is also unaware of the existence in Puyuma of variants with voiced initials $(<* d)$ specialized in counting objects or people: Rikavong Puyuma zowa, Tamalakaw Puyuma zuwa. In the serial-counting series, the most favorable context for list analogy, Rikavong towa ' 2 ' has the same initial as tili ' 3 ', and Tamalakaw tuwa '2' as teri ' $3{ }^{\prime} .{ }^{4}$ It is most likely, then, that we have here the result of alignment on the initial of ' 3 '. Even accepting for the sake of argument the existence of PAn *D_although this proposed phoneme is scantily attested and problematic in several ways - , the match between Ross's *D and Thao $t$ - is extremely weak: of the five Thao words Ross reconstructs with *D, only two have $t$, one of them being tusha '2', which as we have seen is susceptible of another interpretation.

Sagart (2004) reconstructed * RaCep ' 5 '. Ross (2012:1286) thinks that * $\mathrm{RaCeb}$ is the proper reconstruction and that the xasəp-type forms reported for Pazeh are the result of final devoicing. If Ross is right, explaining *pitu '7' on the basis of * RaCeb becomes problematic. The situation with the final consonant in this Pazeh word is complex. Some investigators: Bullock (1874), Thomson (1875:542), Davidson (1903:749), Ferrell (1969) report a voiced consonant, while others: Ino (1898), as reproduced in Li and Toyoshima 2006, \#133, \#134) Ogawa (\#137a), Blust (1999b), Li and Tsuchida (2001) heard - $p$. At the same time Pazeh has a synchronic rule voicing a voiceless stop intervocalically before a word boundary, e.g. alep 'door', aleb-en 'be closed, of a door' (Blust

3 The reconstruction of PAn voiced coronal obstruents is a complex issue which needs separate treatment.

4 The difference between Tamalakaw and Rikavong, two neighboring and otherwise very closely related Puyuma varieties, in the initial consonants of ' 2 ' and ' 3 ' is interesting. Tamalakaw normally reflects PAn *t as $t$. Reflexion of PAn *t in *telu as Tamalakaw $t$ - in teri ' 3 ' is irregular. It seems to show retroflex harmony with the following consonant $-r^{-}$, the regular reflex of PAn *1. The expected $t$ - reflexes are found in the nonserial forms of ' 3 ': Tamalakaw ta-teru, tu-turu- $a$. It is remarkable that accidental retroflexion in ' 3 ' has been transmitted to ' 2 ', Tamalakaw tuwa: this evidently requires an analogical channel. 
1999b:326 $6^{5}$. The coexistence of $-p$ and $-b$ variants for ' 5 ' in a small language community over a period of more than a century is more suggestive of competing variants than of sound change in progress. $x a s a b$ may have arisen in compound numerals (e.g. xasep-i... > xaseb-i...) through Blust's voicing rule, later to be extracted from these compounds, competing with original xasep as ' 5 '. Saisiyat (Ta'ay) Lasəb and Favorlang achab either support Ross's view or acquired a voiced ending through intervocalic voicing, as suggested above for Pazeh. Taokas does not support Ross's view: among those varieties of Taokas which distinguish PAn *p and *b, Hameyan (Ino 1898; reproduced as language \#126 in Ogawa's notebook, reedited as Li and Toyoshima 2006) reflects *p as $p$ and *b as $v$ (nevudam 'sky'<ne-*buN[ə]m 'cloud', yavari 'wind' $<y a-{ }^{*}$ bali, where *ne-and *ya- are unidentified but recurring formatives). Hameyan $v$ appears to have no other source than ${ }^{*} \mathrm{~b}:{ }^{*} \mathrm{w}$ is reflected as $w$. Hameyan allows $v$ in word-final position: yaev 'fuel' . Yet '5' is hasap not *hasav, and ' 50 ' is hasap-a-ta-isid ( $<* \mathrm{RaCep}-\mathrm{a}-\mathrm{sa}-\mathrm{iCit})$ not *hasav-a-ta-isid. Even granting that the voiceless stop at the end of hasap reflected Ross's *-b with final devoicing, one would still expect it to remain voiced in intervocalic position, as in '50'. Reconstructing * RaCep allows one to account for all the evidence without any irregularity, by using the combined resources of regular sound change and analogy.

Ross then turns to left-pruning, assumed at stage 4 in Figure 2. He objects to the pruning of * RaCe- in '7' and ' 8 ', but of *RaCepi- in '9' (Figure 2) as 'irregular'. A change may be called 'regular' when it can be described by an explicit instruction. Change 4 in Figure 2 is described by the instruction 'prune left of pre-tonic syllable'. Applying that instruction necessarily results in segments of different lengths being pruned off, depending on where the tonic (i.e., stressed) syllable is in the input string. Unsurprisingly, Formosan examples exist of uneven prunings: Tungho Saisiyat fajbofi: ' 6 ' (above) has a short variant $b o f i$ : where $\int a j$ - has been pruned off; while $\int a j b o f i$ :o-Pcehce? '7' has the shorter variant joe?cehce? through pruning of fajbof(i)-. ' Presumably Ross regards this as impossible. Finally, Ross objects to my treatment of Luilang patulunai ' 8 ' as coming from * RaCep-a-telu-nai ' $5+\mathrm{LNK}+3+$ nai' (where -nai is a morpheme recurring in '7-8-9', similar to -gal 'take' in Atayal, and LNK is a linker inserted between words ending and beginning in consonants; the pruned-off string is shown in double-strikethrough characters) because "this would leave satulunai '9' unaccounted for" (1286). He himself treats satulunai as subtractive '10-1', with $s a-<*$ isa ' 1 '. If he is right -tulunai must mean 'ten minus_.'. Since patulunai ' 8 ' contains -tulunai too, Ross concludes that patulunai must also be subtractive: '10-2'. However (i) pa- in patulunai

5 "a rule of intervocalic voicing that affects voiceless stops before a morpheme boundary, but not within a morpheme"

6 Listed under 'tree', \#148 in Li and Toyoshima (2006).

7 An anonymous reviewer points out a similar left-pruning intepretation of je? ?cehæe? in a manuscript on Saisiyat by E. Zeitoun. See also fn. 18 below. 
cannot be related to any known form of ' 2 '; (ii) -tulu- without a doubt reflects *telu ' 3 ': it is hard to see how it could mean ' 10 minus'. Finally in my analysis satulunai ' 9 ' is not unaccounted for: that form goes back to *aCep-esa-telu-nai ' $5+1+3$ ', with left-pruning of *RaCepe- (or RaCepi-), leaving the string satulunai on the right. A rule saying 'prune so as to leave the three syllables closest to nai' would do the job exactly; so would any rule defining the string to prune in relation to the stressed syllable in -tulu- 'three', whatever that syllable may have been. The pruning rule in Luilang ' 8 ' and ' 9 ' is of the very same type as the rule proposed at stage 4 of Figure 2: it offers direct support for the prunings assumed in my model. Table 3 recapitulates the proposed developments in these Luilang words:

\begin{tabular}{|c|c|c|c|c|c|c|}
\hline \multicolumn{4}{|c|}{ source form } & \multirow{5}{*}{$\square$} & \multirow{2}{*}{$\begin{array}{c}\text { pruned } \\
\text { RaCe- }\end{array}$} & \multirow{2}{*}{$\begin{array}{r}\text { remaining } \\
\text { patulunai }\end{array}$} \\
\hline RaCep & $\mathrm{a}$ & telu & nai & & & \\
\hline 5 & LNK & 3 & suff. & & & \\
\hline RaCep & esa & telu & nai & & RaCep-e- & satulunai \\
\hline 5 & 1 & 3 & suff. & & & \\
\hline
\end{tabular}

Table 2: left-pruning in Luilang additive forms for '8' and '9'.

In support of his proposal that *Siwa '9' came from *RaCep-i-Sepat, Sagart (2004) cited sipat ' 9 ' in Kalapo, a small settlement in southwest Taiwan, ${ }^{9}$ point M2 in Tsuchida and Yamada (1991:38). sipat is transparently reduced from *RaCepiSipat ' $5+4$ ', with pruning of *RaCepi-. Although sipat is not in the direct line of evolution from * RaCep-i-Sepat to *Siwa according to Figure 2, it is a rare missing link showing preservation of $*_{-}$t, fronting and raising of $*_{\mathrm{e}}$ and absence of lenition in -p-. The language once spoken in Kalapo is extinct but Tsuchida and Yamada characterized it as part of Makatao, which was either a subgroup within Siraya or an independent language. They listed two sets of numerals assembled by Ogawa in that language: one recorded by (or from ?) a local policeman, and another by Mabuchi Toichi, a student of Ogawa's (Table 3).

8 or $*$ RaCep-isa-telu-nai.

9 According to the map in Tsuchida and Yamada (1991:x), Kalapo was located between Gaoshu Township 高樹鄉 and Sandimen Township 三地門鄉 in Pingdong [Pingtung] 屏東 County. Approximative coordinates: latitude 22.79, longitude 120.61 . 


\begin{tabular}{|l|l|l|}
\hline source & policeman at Kalapo & Mabuchi \\
\hline Tsuchida and Yamada code & M2 & M3 \\
\hline 1 & nasa & na-sa-ad \\
\hline 2 & naluha & rad $($ r $)$ uha ${ }^{10}$ \\
\hline 3 & tasa & rad(r)uma \\
\hline 4 & supa & rasipat, nasipat \\
\hline 5 & talima & ralima \\
\hline 6 & ulum & rahurum \\
\hline 7 & pito & rapito \\
\hline 8 & halo & raharu(o) \\
\hline 9 & sipat & rasiwa \\
\hline 10 & kaiten & rakaitian \\
\hline
\end{tabular}

Table 3: two sets of Kalapo numerals collected by Ogawa. Source: Tsuchida and Yamada (1991:3039).

The M3 numerals prefixed with $r a$ - above ' 1 ' are similar to the non-human numeral series in a variety of Thao, ${ }^{11}$ another west coast language, which are prefixed with $l a$-also above ' 1 '. We also see scattered across both sets elements of a numeral series with $n a-$, similar to Babuza, also a westcoast language: nata '1', naroa '2', natoola '3', napat '4' etc. Unfortunately details on usage are not available, whether for Babuza or for Kalapo. The rest of the numerals, i.e. most of the M2 series, look like simple unmarked serial-counting numerals. This probably indicates that the M2 and M3 sets are not the numerals of two widely divergent languages, but distinct series in two closely related languages, or in the same language. Once this is recognized, this material is not particularly strange. M3 na-sa-ad ' 1 ' is Siraya saat ' 1 ' prefixed with $n a-$. Prefixation of $t a$ - in M2 ' 5 ' is not exceptional in a Formosan context (compare talima in Thao \#29e, Siraya \#152, Li and Toyoshima 2006). M2 kaiten, M3 kaitian are the habitual Siraya word for ' 10 ', from *ka-iCi(t)-an. The situation with respect to ' 9 ' is especially interesting: while M2 has sipat, derived from *RaCepiSipat through pruning, M3 has ra-siwa, presumably from ra-sipat with lenition of - $p$ - and loss of final $-t$. The model in Figure 2 did not take into account the existence of distinct series of numerals in Formosan languages. The Kalapo facts suggest that prefixation of $r a$ - is what triggered the other two changes (lenition of $p$ and loss of $-t$ ), and that siwa, the reduced form of ' 9 ', was eventually transferred to the serial counting series, displacing sipat. It cannot be a coincidence that

10 The notation ' $d(r)$ ' seems meant to express hesitation between $d$ and $r$.

11 Based on Thao data recorded by Paul Li Jen-kuei on Eugene Chan's web site Numeral Systems of the World's Languages, http://lingweb.eva.mpg.de/numeral/, accessed Dec. 8, 2013. 
sipat and rasiwa occur in an Enemish language, the group branching off immediately before * Siwa first appears as the serial-counting form of ' 9 '. Naturally, sipat ' 9 ' is an embarrassment for those who deny that *Siwa '9' arose out of *RaCep-i-Sepat ' $5+4$ '. Ross (1287) writes that the Kalapo material is very unreliable, as (i) "other sources listed by Tsuchida and Yamada have either a reflex of *Siwa or the non-cognate matuda"; (ii) 'the source gives tasa for ' 3 ' where other forms give a reflex of *telu"; and (iii) "the source gives supa for " 4 ' 'lacking the $-\mathrm{t}$ that is allegedly retained in sipat '9'". Point (i) is no serious objection: we just saw that ra-siwa in M3 is not the "normal' Kalapo form for ' 9 ' but probably the reduced form of sipat in the ra-prefixed series. As to matuda ' '9', it is an innovation of Siraya proper, never shown by any language in the Makatao cluster. Kalapo lets us glimpse the probable situation in Siraya before the matuda innovation. Point (ii) seems merely to object to the possibility that Kalapo may have innovated for ' 3 '. As to point (iii), a look at Table 3 immediately shows the reason for the lack of $-t$ in supa ' 4 ': changing supat to supa allowed a sequence of five consecutive numerals 1-5 ending in $-a$.

Ross next (1287) echoes the criticism by Winter (2010) that the sound changes used in Sagart (2004) to derive the short numerals *pitu '7', *walu ' 8 ' and *Siwa '9' from PAn additives are ad hoc or irregular, so that the entire proposal is incompatible with the comparative method. As Sagart (2013a) shows, a cross-linguistic tendency for compound numerals to simplify through sound changes not affecting the rest of the lexicon ${ }^{12}$ is known at least since Schmid (1964). It would be impossible to explain forms like Czech čtrnáct '14', Rumanian şaişpe '16', modern Greek $\sigma \alpha \rho \alpha ́ v \tau \alpha$ '40', Cantonese $s a_{1}$-ah-saam ' 33', Danish tres '60' etc., Squliq Atayal mpuw '10', etc., without such changes. No less than seven, applying sequentially and across the board though not outside of compound numerals, are needed to explain the phonetic shapes of the Rumanian short numerals between 11 and 19 (Sagart 2013a). A Formosan example of the same kind can now be cited. The Tsou ${ }^{13}$ cardinals 1-9 as they appear in serial counting are coni ' 1 ', yuso '2', tuyu '3', supata '4', eimo '5', nomə '6', pitu '7', voyu '8', sio '9'. The numerals 11-19 consist of maska via '10 plus' followed by -ucni '1', -ueso '2', -utew '3', -uspota '4', -uemo '5', -unmə '6', -uptu '7', -uvew ' 8 ', - -usio ' 9 '. This last series can be derived from the basic cardinals through prefixation of $u$ - followed by five special changes: change of $\mathrm{i}$ to $\mathrm{y}([\mathrm{j}])$ - that is, loss of syllabicity — when preceded by a vowel and followed by a consonant; loss of the second vowel in a word, if it is followed by a consonant; change of y ([j]) to [e]; change of [a] to [o] after -u-; change of final -a to [ə]. One suspects that prefixation of $u$ - triggered the other changes by adding a syllable and creating

12 Expressions including numerals can also be affected by such changes, cf. English tuppence ['t $\Lambda$ pns] 'two pennies', thruppence ['Orıpns] 'three pennies', ha 'penny ['hejpni] 'half-penny'.

13 The Tsou numeral system discussed here is one of the two described on Eugene Chan's web site Numeral Systems of the World's Languages (http://lingweb.eva.mpg.de/numeral/), accessed Oct. 1, 2013. 
a need for reduction to disyllables - still not fully achieved in the case of -uspotə. The proposal in Sagart (2004) assumes the same kind of development: it conforms to recurrent and well recognized change patterns, and in no way implies an abandonment of the comparative method.

Ross (1287) objects to the reference made in Sagart (2004) to the 'drive to disyllabism' as the force behind the reduction of compound numerals to disyllables. His two objections are that while such a drive exists, it is applied in Sagart (2004) with excessive 'ferocity', and second, that it should not be applied to compounds. The objection from ferocity might as well be used to contend that the shortened compound numerals in Rumanian, Czech, Danish, Cantonese or Tsou, cited above, should not exist. As to the second point, Ross cites Blust (2007) to the effect that compounds are not affected by the drive to disyllabism. This cannot be true of compound numerals: witness Shekhoan Pazeh boodah '6'<*RaCep-esa, Saisiyat bofi: '6' < fajbofi., Saisiyat jorcehae? '7' < fajbofi:o?cehce?, Iban (Acehnese, Maloh, etc.) lapan '8'<*dua 'two' + alap 'fetch' + -an 'two taken away', Malay satu 'one'<*(ə)sa- 'one' + *batu 'stone', Tagalog sampu 'ten' < *sa 'one' + nasal linker + *puluq 'ten', Javanese rolas 'twelve'< loro 'two' + walas 'count back'. Compound numerals on the contrary are a prime target of the drive to disyllabism.

Based on Winter (2010:283), Ross (2012:1287) raises a typological argument: the order of innovations in my model $(7>5>6>8>9>10)$ would, in his words, "give rise to typologically odd systems along the way. For example, Proto Pituish would have * pitu '7' but retain additive numerals on each side, a system which is apparently non-existent among the world's languages". First, of Proto-Pituish's three sisters, two have odd systems: Saisiyat with $6=5+1,7=6+1,8=2 \times 4,9=$ $8+1$ (above concerning ' 9 '), and Luilang is with 6, 7, 8=5+3,9=5+1+3 (cf. above concerning ' 8 ' and '9'). If Saisiyat and Luilang have odd systems, why couldn't the same be true of Proto-Pituish ? Second, the statement that according to my model Proto-Pituish must have had * pitu flanked by additives is incorrect. Sagart (2004:415) characterized the PAN situation with respect to numerals thus: "PAn had a numeration system with stable words for numerals up to ' 5 ', and no stable words for ' 6 ', '7', '8', '9'. Expressions for the corresponding notions were made up on the spot using additive, multiplicative and subtractive strategies." In other words, the early history of Austronesian numerals 6-9 is one in which an original situation of generalized variation between transparent compounds, not all of them additive, gradually gave way to a stable paradigm of synchronically unanalyzable forms. Of the Proto-Pituish numerals 6-9, only *pitu ' 7 ' had no competitors; there were diverse forms in competition for the meanings ' 6 ' and ' 8 '. This is not the situation Winter and Ross described: an unanalyzable form for ' 7 ' flanked by additives. 


\section{Ross's account of the evolution of the numerals}

Ross (1288-1292) defends the traditional view that the six disyllabic numerals 5-10 were part of PAn. His views are that

(1) the Austronesian homeland was in southeastern and south-central Taiwan, the region of present-day Tsou, Rukai and Puyuma. This is a consequence of his subrouping hypothesis, in which these three languages have primary-branch status. Such a location for the Austronesian homeland is curious, considering that the first Austronesians certainly arrived in Taiwan from the adjacent mainland. One would expect an Austronesian homeland located not too far from a point of entry on the west coast. In the words of Starosta (1995:696) commenting on a paper by Li, "it seems to require an airborne invasion into the interior".

(2) PAn had a decimal system with all of *lima ' 5 ', *enem ' 6 ', * pitu '7', *walu ' 8 ', *siwa ' 9 ' and *puluq ' 10 '. This decision is a consequence of the fact that Puyuma has these six numerals and that Tsou and Rukai have the first five.

(3) In addition to *puluq PAn had a second form for ' 10 ': *ma[y]saL, which served in counting objects and in ' 11 ' to '19', while *puluq was 'cardinal 10'. The addition of *ma[n]saL to Ross's list of PAn numerals is made necessary by the fact that Tsou has maska ' 10 ' < Ross *ma-sa-L ${ }^{14}$ and (Tanan) Rukai has mayaala ' 10 ' in counting objects and as part of the numerals ' 11 ' to '19'. Ross sees Tanan mayaala as coming from a PAn *man-sa-L. Taking the presence or absence of - $n$ - and -ə- to be negligible, he conflates this with his *ma-sa-L into a "PAn *ma[y]saL". One recognizes there the decade-forming circumfix *ma-...-L (my *ma-...-N) and *sa, a short version of PAn *isa or *esa ' 1 '. There are two problems. First, Tanan Rukai mayaala is an innovative form based on Tanan $\partial a ́$ ' 1 ' (serial), $ә a$ ' 1 ' (counting objects), decade-forming *ma-... -N circumfix (above) and - $\eta$ - breaking a sequence of vowels, as in $t a-\eta$ - $\partial a$ ' 1 ' (counting people). It is not an inherited form. ${ }^{15}$ Second, Proto-Rukai *puLuku, regarded by Ross as the inherited reflex of *puluq '10', must be a loan from Paiwan, where (unlike in Rukai) *q is retained (as noticed in Li 2006, Zeitoun 2007:253). Thus Rukai reflects neither *may-sa-L nor *puluq, and the division of labor between them, which Ross bases on Proto-Rukai and ultimately projects onto PAn, turns out to be an illusion. No Austronesian language shows the suppletion pattern supposed by Ross for ' 10 '. That proposal is the fruit of the interaction between two of his

14 Ross's *ma-sa-L cannot explain the glottal stop in Bunun mac?an: the PAn form must be *ma-sa?a-N, with syncope of the unstressed penultimate vowel in Bunun. The unit numeral used with the *ma-...-N circumfix was *sa?a, the 'stretched' form of *sa 'one' rather than *sa itself. Unit numbers used with *ma-...-N to form decade terms are all disyllabic, whence the choice of *sa?a in preference to *sa ' 1 '.

15 Tanan data are drawn from Eugene Chan's website Numeral Systems of the World's Languages (http://lingweb.eva.mpg.de/numeral/Austronesian), accessed Oct 5, 2013. The correct segmentation in Mantauran Rukai of the second form for '10' is given in Zeitoun (2007:255): ma-nge-le. 
presuppositions: that Tsou and Rukai are primary branches, and that *puluq was part of PAn.

(4) The descendant languages spread out of the homeland region to the rest of Taiwan. This involves a movement from southeastern and south-central Taiwan to the west coast. However, archaeologist Hung Hsiao-chun (2008:73) sees movement in the reverse direction: "During the Middle Neolithic, one of the obvious cultural movements inside Taiwan was from the southwest to the eastern coast". She views this influence as due to a migration caused by demographic factors: “(...) the apparent large Middle Neolithic population in western Taiwan was a main cause of the migration (...)". The most conspicuous consequence of that population movement was the rise to prominence of the east coast after $2500 \mathrm{BCE}$ : "Compared with other regions, eastern Taiwan has the highest growth-rate in terms of site numbers" (in the Middle Neolithic period, post $2500 \mathrm{BCE}$ ) (Hung 2008:71-72). This fits particularly well with the model in Sagart $(2004,2008)$ which has Puluqish, a group located on the southeastern and south coasts, individualizing out of WaluSiwaish, centered in the southwest, and Walu-Siwaish itself originating in Enemish, centered on the southwest coast. Ross's model goes smack against it.

(5) In the course of their expansion on the west coast, the early Austronesians encountered paleolithic populations ('Changpinians') speaking languages with quinary counting systems; contact with these groups led the Austronesians into acquiring characteristics of quinary counting systems. However this view of Ross's does not fit particularly well with archaeology: archaeological evidence for Changpinian is limited to the east coast and the extreme south (Chang 1971, Chao 2000). Few compound numerals can be found in the modern Formosan languages spoken in those regions. Moreover, we also know that quinary counting systems exist on the East Asian mainland: in Khmer, ${ }^{16}$ an Austroasiatic language, and more vestigially in Sino-Tibetan (the Sino-Tibetan word for '7' includes '2': Benedict 1972:93). It would not be strange for a mainland language reaching Taiwan c. $3500 \mathrm{BCE}$ to have had a counting system of this type.

(6) Interaction on the east coast between Austronesians and 'Changpinians' did not give rise to any changes in the direction of quinary counting systems. Ross gives no explanation for this. Yet if contact between early Austronesians and 'Changpinians' occurred anywhere, it must be on the east coast, where pre-Austronesian sites concentrate. Were Changpinian counting systems perhaps quinary on the west coast and decimal on the east coast ? Ross doesn't say, but this claim should probably be part of his theory.

Table 7 in Ross (2012:1290), modified from Table 1 in Sagart (2004) lists the numerals 5-10 in Formosan languages. The forms Ross considers to be innovations are indicated. That table contains factual errors in the two columns for ' 10 ', where Ross has introduced new data. Amis

16 Khmer has $1,2,3,4,5,6=5+1,7=5+2,8=5+3,9=5+4,10$. 
puluq and mu?tep have been interverted: the first is a teen form, the second a cardinal. Second, Siraya $\ddot{a} b$ is not a numeral. It means 'plus', not 'ten' or '-teen', or '-ty'. Example: sa-saat kĭtiän äb ki ruha '12' is composed of sa-saat '1', kittïn '10', äb 'plus', ki LINKER and ruha '2'.

Ross's model throws little light on early Austronesian numeral history. He attempts to explain why *pitu ' 7 ' is preserved in more west-coast languages than *Siwa 'nine'. This is so, he claims, because "there is a straightforward subtracting strategy to encode the odd number ' 9 ' with a compound (10-1) but not ' 7 '” (p. 1291). In this, he overestimates the number of subtractive formations for ' 9 ', and underestimates that of additive formations for ' 7 '. ${ }^{17}$ Thus he treats (2012:1286, 1291) Luilang satulunai '9' as subtractive 10-1 when it is really additive 8+1 (above, section 3 ). Similarly (2012:1291), he treats Ta'ai Saisiyat lceæ?hce? '9' as being from 10-1 because it contains ?cehce? ' 1 '. However, in several other varieties of Saisiyat, the word for ' 9 ' begins in t- < *t: Saisiyat \#123e, tayaha \#123f taha (Li and Toyoshima 2006), pointing in the direction of a pruned-off word ending in -t. This makes Saisiyat kafpat ' 8 ' a likely candidate. If so Ta'ai loece?he? (together with its regular Tungho cognate cece?hoe?) most likely goes back to the additive ?cehce? ' $8+\mathrm{a}+1$ ', with -t- preserved as a stop in \#123e,f, and intervocalically lenited to $l$ - in Ta'aiA. ${ }^{18}$ Ross cannot explain the alternation between $b$-forms and $w$-forms in ' 8 ' and ' 9 ' in Amis, Rukai and Paiwan (Table 1), as we have seen.

Above all, Ross has no explanation for the hierarchy of implications described in section 1 and its spatial consequence: the distribution of isoglosses shown in Figure 3.

17 He calls Saisiyat fajbofi:-o-?cehce? '7' $(<6+1)$ 'extraordinary' (1291).

18 According to an anonymous reviewer, the same account of the origin of the Saisiyat word for ' 9 ' can be found in a forthcoming book on Saisiyat by E. Zeitoun. See also fn. 7 above. 


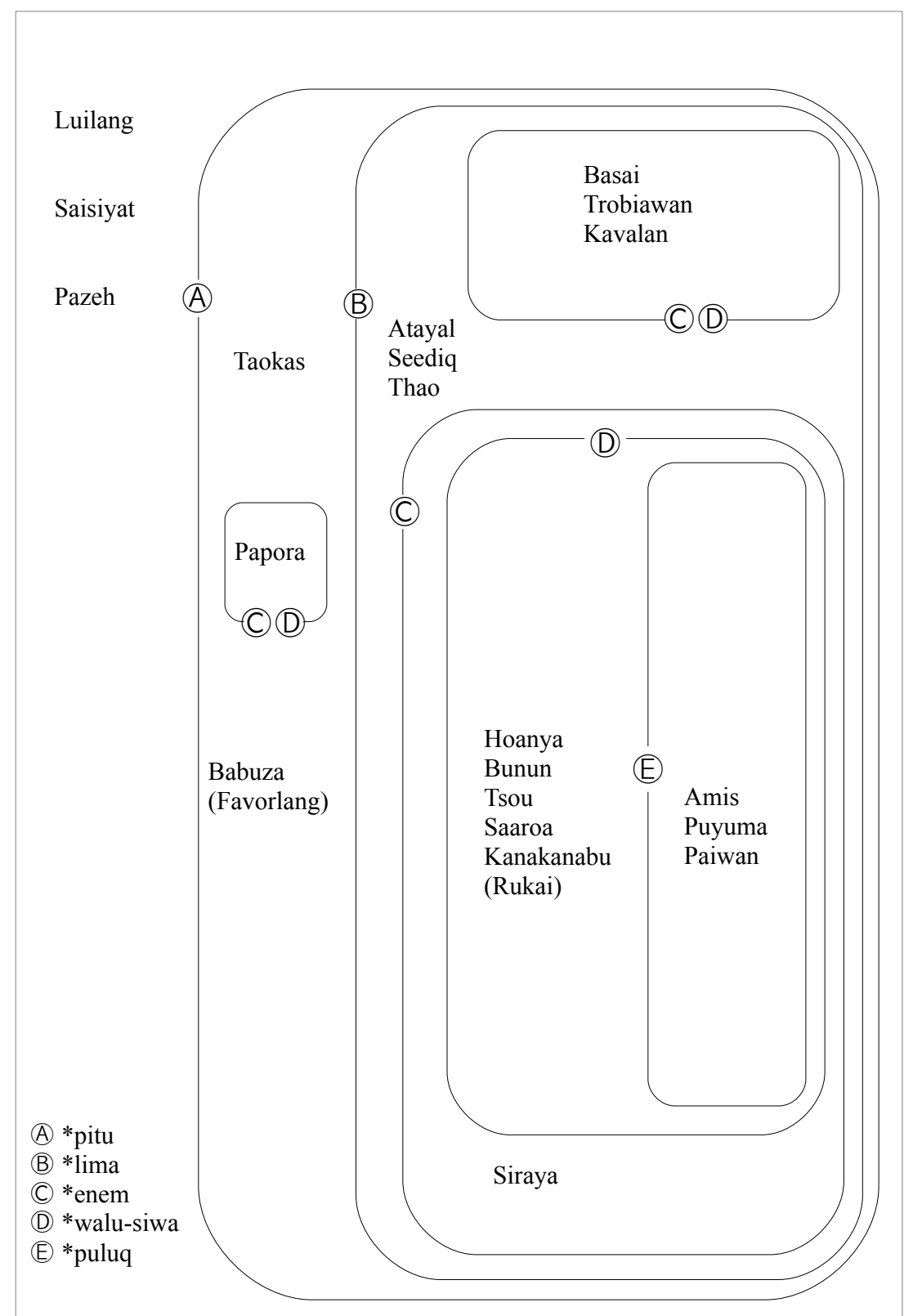

Figure 3: nested innovative isoglosses for the short numerals in Taiwan. Rukai has a local innovation instead of *Siwa.

Figure 3 shows single isoglosses (A) (*pitu '7'), (B) (*lima '5') and (E) (*puluq '10'), spatially nested as $(E) \subset(B) \subset A$ A ${ }^{19}$ against three distinct isoglosses for each of $(C)$ (*enem ' 6 ') and (D) (*walu ' 8 ', *Siwa '9). (C) and (D) coincide in the north and the west, while (D) is included within (C)in the south. This is easily explained. The southern pattern: (D) $\subset$ (C), displays the original situation. It is due to the * walu and *Siwa innovations having occurred simultaneously in one daughter language of proto-Enemish, the language where *enem was established as ' $6{ }^{\prime} \cdot{ }^{20}$ The coincidence of (C) and (D) in the north and west is the result of the geographic isolation - for whatever reason: migration or

19 The symbol ' $\subset$ ' is used here to mean 'geographically included in'.

20 *Siwa is not reflected in Rukai, having been displaced there by the local innovation bayata '9', of unknown origin. 
intrusion of third-party languages - of two groups originally within the (D) isogloss. We may thus restore the overall situation before these events: a perfect nesting pattern, (E) $\subset$ (D) $\subset$ (C) $\subset$ (B) $\subset$ (A), with Luilang, Saisiyat and Pazeh outside of (A) in the west and northwest. Sagart (2013a) has invited critics to explain this pattern, pointing out that it is only explainable if the isoglosses in it are innovative.

Ross's treatment of the spatial distribution of Formosan numerals does not go beyond stating that innovative numerals are found in western Taiwan. He has nothing to say about the spatial nesting of short numerals shown in Figure 3 (remember that these isoglosses according to him enclose retentions from PAn). Neither can he explain the spatial distribution of (what he regards as) the innovative long-numeral isoglosses: he finds that the geography of quinary-like innovations on the west coast "border(s) on chaos" (1291); yet "this is not surprising" (1292) because "for a considerable period of time after the dispersal of PAn, its daughters must have formed a network in which discrete subgroups were the exception rather than the rule (...) and the spread of innovations would not have been prevented by subgroup boundaries" (1292). A situation such as this -orderly spatial nesting of retentions, random criss-crossing of innovations-is contrary to experience: nested isoglosses are classically viewed in dialect geography as the signature of sequences of innovations arising in a single center (so Goossens 1969:51 for the nesting of isoglosses for successive stages in the broadening of the context of a consonant change in Limbourg; Labov, Ash and Boberg 2006:43, 119, and maps 11.4, 11.7 for the spatial nesting of isoglosses corresponding to qualitatively different stages in American English vowel shifts). The principle reason for this is that the spatial patterns which result from innovations are necessarily more recent than, and must necessarily overlay, whatever spatial patterns characterized the retentions from a proto-language. Outside of linguistics, this principle, or a very similar one, is increasingly made use of by Nested Clade Theory (Templeton et al. 1995, Templeton 1998), a branch of phylogeography which aims at reconstructing intra-species biological histories on the basis of the spatial patterns of DNA-defined clades. Here, even supposing for the sake of argument that Ross is right about the reason behind the lack of spatial patterning of the isoglosses he treats as innovative, the orderly pattern of the isoglosses he regards as retentive is still inexplicable.

Blust (2009:741) suggested that instead of being a product of chronologically successive innovations, the implicational relationships among the short numerals may have resulted from what he calls "patterned losses". This seems to mean that the several innovations which, independently from one another, have been eating at, and reducing the geographical extent of, each of the six PAn isoglosses from *lima ' 5 ' to *puluq ' 10 ' have playfully conspired to do so in such a way as to leave a matryoschka-doll pattern behind them. In the absence of a linguistic motivation for such a 
development, Blust's suggestion seems little different from one attributing to chance the nesting pattern in six characters forming a natural set.

\section{Tsouic}

Tsouic is a Formosan subgroup, first proposed in Ferrell (1969:63sq) on lexicostatistical grounds. It includes Tsou, Kanakanavu and Saaroa, three languages spoken in the mountainous regions of central southern Taiwan. Kanakanavu and Saaroa are close to each other linguistically and form a southern subgroup within Tsouic. Tsuchida (1976) worked out the phonological history of Tsouic and reconstructed a Proto-Tsouic lexicon. In the framework of Sagart (2008) Tsouic is a subgroup of Walu-Siwaic (i.e. the languages which innovated *lima '5', *enem ' 6 ', *pitu '7', *walu '8' and *Siwa '9' but not *puluq '10'). Tsouic clashes with Ross's phylogeny because it puts together Tsou, a primary branch in his scheme, with two of his Nuclear Austronesian languages: Kanakanavu and Saaroa. Ross rejects Tsouic exclusively on the basis of negative evidence, always a dangerous tool. He states that the only argument presented by Tsuchida in support of this subgroup is lexicostatistically-based (Ross 2012:1302). This is inaccurate, as we shall see. He also points out differences between Tsou and Kanakanavu-Saaroa in phonological structure and morphosyntax, finding no evidence of shared innovations in either domain. He ascribes any resemblances between Tsou and the southern Tsouic languages to contact.

\subsection{Tsouic and the evidence from sound change}

Given the inherent tendency of regular sound change to cross language boundaries, the apparent lack of uniquely shared phonological innovations is not surprising, nor should it count against Tsouic. In fact Tsouic evidence can be found of exclusively shared irregular or sporadic sound changes, more diagnostic than regular ones as argued above: the metathesis of *pataS 'tattoo, write' > Proto-Tsouic *tapaSə (Kanakanavu tapásə, Saaroa taa-tapa-a, Tsou ta-tpos-a 'pattern, design'); and the irregular change of PAn ${ }^{*} \mathrm{C}$ - (Tsuchida's $\left.{ }^{*} \mathrm{C}_{1}\right)$ to Proto-Tsouic $* \mathrm{t}$ - in ${ }^{*}$ Caqi 'excrement'> Proto-Tsouic *tá ${ }_{3}$ i (Kanakanavu táa?i, Saaroa tiiii, Tsou t?ee 'excrement'). Should one suppose that *tapaSə and *tá ${ }_{3} \mathrm{i}$ were PAN forms inherited unchanged by Tsou, Kanakanabu and Saaroa, *pataS and *Caqi would have to be innovations at an 'extra-Tsouic' node ancestral to all other Austronesian languages: but that node too would clash with Ross's phylogeny.

\subsection{Tsouic and morphosyntactic innovations}

Lack of shared morphosyntactic innovations of Tsouic ought to be considered in light of the highly innovative character of Tsou verbal morphosyntax. Tsou has generalized auxiliary verbs with the result that Tsou verbal morphology is now to a large extent reduced to its former dependent-verb 
component. That has erased whatever earlier innovations in non-dependent verbal morphology Tsou may have previously shared with Kanakanabu and Saaroa. This, however, should not be taken to mean that no morphosyntactic characters clash with Ross's theory. Thus, certain Formosan languages use a special series of numerals when counting nonhuman referents: Siraya and Puyuma use CV-reduplication while the three Tsouic languages, plus Karei Rukai (Ino 1898) and Kavalan use a prefix $u$-. This poses a difficult problem to Ross's theory: both sets of Formosan languages, those which use $\mathrm{CV}$ - reduplication and those which prefix $u$-, associate languages that are primary branches in Ross's scheme and 'Nuclear Austronesian' languages. Ross would have to suppose that in counting nonhuman referents PAn used both CV-reduplication like Puyuma, and $u$-prefixation like Tsou and Rukai.

Tsou eccentricity is not limited to morphosyntax: Tsou phonology also stands out in a Formosan context, with unusual clusters of consonants and of vowels. The probable underlying cause of Tsou eccentricity in general is to be sought in the isolation of a small Tsou group after the break-up of Proto-Tsouic, with eccentric tendencies not counterbalanced by contact with the outside world.

\subsection{Tsouic and lexical innovations}

Ross assumes that published evidence supporting Tsouic is entirely based on lexicostatistics. He overlooks the numerous Proto-Tsouic forms in Tsuchida (1976, appendix B). A good part of these has no cognates outside of Tsouic. Here is a conservative list of 57 Tsouic-only items: ${ }^{21}$
1. *cáni 'one' (serial counting);
13. *-láku 'fetch water';
2. *-cəkə́łə 'come, arrive';
14. *lápátə 'bark of tree';
3. *čalíri 'dream';
15. *láwa[y]i 'to set' (of the sun or moon);
4. *čarápunu 'hat';
16. *-lə́mə́kə 'to plant';
5. *čupúłu 'runner of vines';
17. *-1 $1_{1}$ əməčə 'throat';
6. *huúru 'cooked rice';
18. *liámə 'to fly';
7. ' * $k_{1}$ ałál $l_{1} u \tilde{a}$ 'older sibling';
19. *líčú 'muddy pool where animals
8. *-k $\mathrm{k}_{1}$ árúmi 'to use'; wallow';
9. *ma-kínayi 'be given';
20. *ma-ličúwว́łə 'heavy',
10. *-kitə்orə 'stretched tightly';
21. *łálunu 'miscanthus';
11. *kułúkułu 'type of heron';
22. *láruy- 'sweat';
12. *kúrúłu 'wax tree' (Rhus succedanea);
23. *-łávasə 'drunk';

21 The forms in this list are reflected in Tsou and in at least one southern Tsouic language. 

24. *timúru 'blood';
42. *Oíamə 'spicy, peppery';
25. *-lúčanə 'man' (male);
43. *Oúsárə 'land on the mountain slope';
26. *yírí 'hemp';
27. *palúnu 'base of a tree';
44. *-Səmakə 'to swell, of rice when cooked';
28. *páłu 'steam, vapor';
45. *tałavikárə ‘yellow';
29. *pánarə 'flat';
46. *tarávanə 'Allium odorum';
30. *-pára 'mount';
47. *tarúna 'trachea';
31. *parázaSə 'tree nettle' (Laportea sp.);
48. *tílíti 'hang on a hook';
32. *púlakə 'hip bone';
49. *váakulu 'type of bird';
33. *puupúuyã 'short bamboo container';
50. *vóla日ə 'pith of rattan';
34. *? ${ }_{1}$ alápunu 'feather';
51. *vakúrayi 'type of tuber';
35. *? ${ }_{1}$ arinuái 'type of reed';
52. *valáku 'fur';

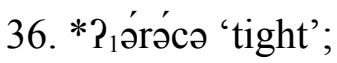
53. *vałáwu 'to dry fur';
37. *? 2 uici 'vine';
54. *varə́varə 'sharp';
38. *rałว́nə 'leaf';
39. *ránácə 'Ipomoea spp.';
55. *viná ${ }_{2} \mathrm{u}$ 'black alder' (Alnus formosana);
40. *-rúván-ã 'evening';
41. *-Oakái 'shrimp';
56. *vúláła 'small stream made by heavy rain';
57. *walúwálu ‘deer species' (Cervus taiouanus).

There is only one way in which this material could pose no threat to Ross's theory: if it was the result of contact between Tsou and Kanakanavu-Saaroa. However there is no semblance that contact can explain more than a few items in the list: the comparisons exhibit Tsuchida's carefully established intra-Tsouic sound correspondences, which he has also related to PAn phonemes. Neither does the list show the kind of cultural slant one expects of borrowings. Indeed, Sagart (2013b) has identified two secure Tsouic innovations in the most basic vocabulary: *cáni 'one' (serial) and *ramuCu 'hand'.

The evidence for Tsouic, then, includes two confirmed lexical innovations in the most basic vocabulary, over fifty candidate lexical innovations and two lexically conditioned sound changes. The quality and quantity of the lexical evidence for Tsouic is such that the Tsouic group appeared in $100 \%$ of the best trees in the massive Bayesian study of Gray, Drummond and Greenhill (2009). Ross's 'Nuclear Austronesian' appeared in none. It is true that evidence of uniquely shared Tsouic innovations in morphology and phonology is still missing, but there are reasons. In conclusion, Tsouic is a well-supported Formosan subgroup. It fits without a single clash in Sagart's phylogeny (Figure 1), but represents a very serious obstacle to Ross's scheme. 


\section{Conclusion}

This paper has addressed three main issues: (1) Ross's criticism of the numeral-based model of early AN phylogeny, (2) Ross's own account of the development of AN numerals, and (3) the evidence for Tsouic. Concerning the first, it has shown that a part of the criticisms in Ross (2012) is addressed to a version of Sagart's proposal that Ross has invented, while another part relies on apparently strict principles which are in fact contradicted by experience: (i) a sound change will not affect compound numerals only; (ii) a pruning rule will always remove the same string of phonemes; (iii) the Austronesian drive to disyllabism will not affect compound numerals. Regarding the second issue, it has shown that Ross's account cannot explain the phonological idiosyncrasies affecting the numerals 5-10, the nesting of short numerals across Formosan languages or the distribution in space of their isoglosses. The retentions Ross's model assumes behave spatially like innovations should, while its innovations are spatially chaotic: this is the reverse of our expectations. Finally this paper has shown that a respectable body of evidence supports Tsouic, a group which clashes with Ross's phylogeny. Only the model proposed in Sagart $(2004,2008)$ explains implicational relationships among numerals, nesting patterns among isoglosses while accommodating the Tsouic subgroup and providing numeral etymologies that are more sophisticated and more attentive to detail than Ross's.

\section{References}

Adelaar, Alexander. 1992. Proto-Malayic: the reconstruction of its phonology and parts of its morphology and lexicon. Pacific Linguistics C-119, Canberra: Research School of Pacific Studies, Dept. of Linguistics, Australian National University.

Adelaar, Alexander. 2011. Siraya, retrieving the phonology, grammar and lexicon of a dormant Formosan language. Berlin: de Gruyter Mouton.

Benedict, Paul K. 1972. Sino-Tibetan: a Conspectus. Cambridge: University Printing House.

Blust, Robert A. 1977. The Proto-Austronesian pronouns and Austronesian subgrouping: a preliminary report. University of Hawai'i working papers in Linguistics 9, 2:1-15.

Blust, Robert A. 1999a. Subgrouping, circularity and extinction: some issues in Austronesian comparative linguistics. Selected Papers from the Eighth International Conference on Austronesian linguistics, ed. by Elizabeth Zeitoun and Paul Jen-kuei Li, 31-94. Taipei: Institute of Linguistics (preparatory office).

Blust, Robert A. 1999b. Notes on Pazeh Phonology and Morphology. Oceanic Linguistics 38, 2: 321-365.

Blust, Robert A. 2007. Disyllabic attractors and anti-antigemination in Austronesian sound change. Phonology 24: 1-36. 
Blust, Robert A. 2009. The Austronesian languages. Canberra: Pacific Linguistics.

Bullock, Thomas Lowden. 1874. Formosan dialects and their connection with the Malay. Chinese Review III: 38-46.

Cao Zhiyun et al. 曹志耘主編. 2008. Hanyu fangyan dituji 漢語方言地圖集 [Linguistic Atlas of Chinese dialects], Yuyin juan 語音卷 [volume on phonetics]. Beijing 北京: Shangwu 商務.

Chan, Eugene. n.d. Numeral systems of the world's languages. Accessed online Oct. 1, 2013 at http://lingweb.eva.mpg.de/numeral/.

Chang, Kwang-chih. 1971 Review article of 'Changpinian: A newly discovered pre-ceramic culture from the agglomerate caves on the east Coast of Taiwan (preliminary report)', by Wen-hsun Sung. Asian Perspectives 12:133-36

Chao, Chin-yung 趙金勇. 2000. Donghai'an Changbin diqu shiqian yizhi kongjian fenbu chutan 東 海岸長濱地區史前遺址空間分佈初探 [Preliminary study on the spatial distribution of the archaeological sites in Changpin area, eastern Taiwan]. Tian'ye kaogu 田野考古 [Field Archaeology of Taiwan] 1/2:19-44.

Coblin, W. South. 2007. Development of modern Chinese phonology: from Guānhuà to Mandarin. Paris: Collection des Cahiers de Linguistique Asie Orientale.

Davidson, James W. 1903. The island of Formosa, past and present. London and New York: Macmillan and Co. Accessed online Oct. 1, 2013 at https://archive.org/stream/islandofformosap00davi\#page/n749/mode/2up.

Ferrell, Raleigh. 1969. Taiwan Aboriginal groups: problems in cultural and linguistic classification. Monograph No. 17, Institute of Ethnology, Academia Sinica. Taipei: Academia Sinica.

Goossens, Jan. 1969. Strukturelle Sprachgeographie, eine Einführung in Methodik und Ergebnisse. Heidelberg: Carl Winter. Universitätsverlag.

Gray, Russell D., Alexi J. Drummond and Simon Greenhill. 2009. Language Phylogenies Reveal Expansion Pulses and Pauses in Pacific Settlement. Nature, 323, 479-483.

Heine, Bernd. 1997. Cognitive foundations of grammar. Oxford: Oxford University Press.

Hung, Hsiao-chun. 2008. Migration and Cultural Interaction in Southern Coastal China, Taiwan and the Northern Philippines, 3000 BC to AD 100: The Early History of the Austronesianspeaking Populations. Unpublished PhD dissertation, Canberra: the Australian National University.

Ino, Yoshinori 伊能嘉矩. 1998. 巡臺日程 [A Formosan itinerary]. In 伊能嘉矩番語調查手冊 [Ino Yoshinori's field records], ed. by : T. Moriguchi, pp. 13-201. Taipei: Southern Materials Center.

Kingston, John. 2008. Lenition. Selected Proceedings of the 3rd Conference on Laboratory Approaches to Spanish Phonology, ed. by Laura Colantoni and Jeffrey Steele, 1-31. Somerville, MA: Cascadilla Proceedings Project.

Labov, William, Sharon Ash and Charles Boberg. 2006. The Atlas of North American English: Phonetics, phonology and sound change. Berlin: Mouton/de Gruyter.

Li, Jen-kuei, Paul. 1995. Formosan vs. non-Formosan features in some Austronesian Languages in Taiwan. Austronesian Studies Relating to Taiwan, ed. by Paul Jen-kuei Li, Dah-an Ho, Ying-kuei Huang, Cheng-hwa Tsang, and Chiu-yu Tseng, 651-681. Symposium series of the Institute of History and Philology, Academia Sinica, no. 3. Taipei: Academia Sinica. 
Li, Jen-kuei, Paul. 1999. Some problems in the Basay Language. Selected papers on Formosan languages, Vol. 1, 479-509. Taipei: Academia Sinica.

Li, Jen-kuei, Paul. 2004. Selected papers on Formosan languages. Taipei: Institute of Linguistics, Academia Sinica.

Li, Jen-kuei, Paul. 2006. Numerals in Formosan languages. Oceanic Linguistics 45, 1: 133-152.

Li, Jen-kuei, Paul and Masayuki Toyoshima (eds). 2006. Comparative vocabulary of Formosan languages and dialects, by Naoyoshi Ogawa. Asian and African lexicon series 49. Tokyo:

Institute for Languages and cultures of Asia and Africa, Tokyo University of Foreign Studies.

Li, Jen-kuei, Paul and Shigeru Tsuchida. 2001. Pazih dictionary. Taipei: Institute of Linguistics (preparatory office), Academia Sinica.

Li, Jen-kuei, Paul and Shigeru Tsuchida. 2001. Pazih texts and songs. Taipei: Institute of Linguistics (preparatory office), Academia Sinica.

Marck, Jeff. 2000. Topics in Polynesian languages and culture history. Canberra: Pacific Linguistics.

Ostapirat, Weera. 2000. Proto-Kra. Linguistics of the Tibeto-Burman Area 23.1.

Ostapirat, Weera. 2005. Tai-Kadai and Austronesian: notes on phonological correspondences and vocabulary distribution. In L. Sagart, R. Blench and A. Sanchez-Mazas (eds) The peopling of East Asia: Putting together Archaeology, Linguistics and Genetics 109-133. London:

RoutledgeCurzon.

Ringe, Don, Tandy Warnow and Ann Taylor. 2002. Indo-European and computational cladistics. Transactions of the Philological Society 100,1: 59-129.

Ross, Malcolm D. 2009. Proto Austronesian verbal morphology: a reappraisal. Austronesian historical linguistics and culture history. A festschrift for Robert Blust, ed. by Alexander Adelaar and Andrew K. Pawley (eds), 285-316. Canberra: Pacific Linguistics.

Ross, Malcolm D. 2012. In defense of Nuclear Austronesian (and against Tsouic). Language and Linguistics 13, 6: 1253-1330.

Sagart, Laurent. 2004. The higher phylogeny of Austronesian and the position of Tai-Kadai. Oceanic Linguistics 43, 2: 411-444.

Sagart, Laurent. 2006. The PAN words for '7', '8', '9' and Austronesian subgrouping. Powerpoint presentation at the 10th International conference on Austronesian linguistics. Puerto Princesa, Philippines, 17-23 January, 2006.

Sagart, Laurent. 2008. The expansion of setaria farmers in east asia: a linguistic and archaeological model. Past human migrations in East Asia: matching archaeology, linguistics and genetics, ed. by Alicia Sanchez-Mazas, Roger Blench, Malcolm Ross, Ilia Peiros, Marie Lin, 133-157.

Routledge Studies in the Early History of Asia. London: Routledge.

Sagart, Laurent. 2009. PAn morphology in phylogenetic perspective. Paper presented at the Panel on Reconstruction of PAn morpho-syntax and implications for the Austronesian settlement of Taiwan. 11th International Conference on Austronesian Languages. June 22-25, Aussois, France.

Sagart, Laurent. 2010a. Is Puyuma a primary branch of Austronesian ? Oceanic Linguistics 49, 1: 194-204. 
Sagart, Laurent. 2010b. Why does the Tai-Kadai word for 'ten' end in -t ? Paper presented at the 23 èmes Journées de Linguistique d'Asie Orientale, Paris, July 1-2, 2010.

Sagart, Laurent. 2013a. The Higher Phylogeny of Austronesian: A Response to Winter. Oceanic Linguistics 52.1: 249-255.

Sagart, Laurent. 2013b. Is Puyuma a primary branch of Austronesian ? A rejoinder. Oceanic Linguistics 52, 2: 481-92.

Schmid, Heinrich. 1964. Zur Entwicklungsgeschichte der romanischen Zahlwörter. Vox Romanica 23, 186-238.

Starosta, Stanley. 1995. A grammatical subgrouping of Formosan languages. Austronesian Studies Relating to Taiwan, ed. by Paul Jen-kuei Li, Dah-an Ho, Ying-kuei Huang, Cheng-hwa Tsang, and Chiu-yu Tseng, 683-726. Symposium series of the Institute of History and Philology, Academia Sinica, no. 3. Taipei: Academia Sinica.

Suenari, Michiko. 1969. A preliminary report on Puyuma language (Rikavong dialect). Bulletin of the Institute of Ethnology, Academia Sinica, 27:141-163.

Templeton, Alan, R., Eric Routman and Christopher A. Phillips. 1995. Separating Population Structure from Population History: A Cladistic Analysis of the Geographical Distribution of Mitochondrial DNA Haplotypes in the Tiger Salamander, Ambystoma tigrinum. Genetics 140, 2: 767-782.

Templeton, Alan R. 1998. Nested clade analyses of phylogeographic data: testing hypotheses about gene flow and population history. Molecular Ecology 7, 4: 381-397.

Thomson, John. 1875. The straits of Malacca, Indo-China, China or ten years'travel, adventures and residence abroad. London: Sampson Low, Marston, Low and Searle. Accessed online at http://archive.org/stream/straitsmalacca00thomrich\#page/542/mode/2up.

Tsuchida, Shigeru. 1976. Reconstruction of Proto-Tsouic phonology. Tokyo: Study of languages and cultures of Asia and Africa monograph series $\mathrm{N}^{\circ} 5$.

Tsuchida, Shigeru. 1980. Puyuma (Tamalakaw dialect) vocabulary with grammatical notes and texts. in Kuroshio no Minzoku, Bunka, Gengo, 183-307. Tokyo: Institute for the study of languages and cultures of Asia and Africa, Tokyo University of Foreign Studies.

Tsuchida, Shigeru. 1981. Unpublished wordlists of Amis dialects collected in 1980-81. Tokyo: University of Tokyo.

Tsuchida Shigeru and Yukihiro Yamada (1991) Ogawa's Siraya/Makatao/Taivoan (comparative vocabulary). Linguistic materials of the Formosan sinicized populations I: Siraya and Basai, ed. by Shigeru Tsuchida, Yukihiro Yamada and Tsukenazu Moriguchi, 1-194. Tokyo: The University of Tokyo, Linguistics Department.

Winter, Bodo. 2010. Squib: A note on the higher phylogeny of Austronesian. Oceanic Linguistics 49, 1: 282-287.

Wolff, John U. 2010. Proto-Austronesian phonology with glossary. 2 volumes. Ithaca: Cornell Southeast Asia program publications.

Zeitoun, Elizabeth. 2007. A grammar of Mantauran (Rukai). Language and Linguistics monograph series A4-2. Taipei: Institute of Linguistics, Academia Sinica. 